\title{
PROBLEMATIKA IMPLEMENTASI HUKUM ISLAM TERHADAP PERKAWINAN DI BAWAH UMUR DI INDONESIA
}

\author{
Ahmad Izzuddin \\ Fakultas Syari'ah UIN Maliki Malang \\ Telepon: 08155130764 \\ Email:ashfazudin@yahoo.co.id
}

\begin{abstract}
The general principle of syariah states that legal majority comes with physical puberty. Hence in theory, capacity to conclude a marriage contract basically depends upon proof of sexual maturity established under the normal rules of evidence rather than the attainment of a specific age. In examining the statutory measures on child marriage, it appears that the Compilation follows two main objectives; restriction and indirect prohibition. Since Muhammad himself married Aisyah at an exceedingly tender age, so it is almost impossible for pious Muslims to condemn the practice. A punitive approach to child marriage would also seem unlikely to achieve a desirable result. The indirect means was therefore justified on the basis of the siyasah syar'iyah doctrine; instead of declaring the minor marriage void, the Compilation confined themselves to discouraging it by administrative expedients.

Prinsip umum dari Syariah menegaskan bahwa batas usia pernikahan disesuaikan dengan pubertas fisik. akan tetapi secara teoritis, kapasitas seseorang untuk menikah pada dasarnya disesuaikan dengan kematangan secara seksual dan bukan hanya dibatasi pada usia tertentu. Dalam pengaturan persoalan konteks perkawinan usia dini, KHI menekankan dua hal yaitu pembatasan dan pelarangan secara tidak langsung. Dikarenakan Muhammad menikahi Aisyah pada usia yang masih dini, maka hampir tidak mungkin bagi seorang Muslim untuk mengecam praktek perkawinan usia dini. Suatu pendekatan yang bersifat menghakimi terhadap persoalan tersebut nampaknya tidak akan mencapai hasil yang baik. Dengan demikian, alat yang secara tidak langsung bisa digunakan untuk melihat persoalan tersebut adalah dengan mengembalikan hukum pernikahan usia dini berdasarkan siyasah syar'iyah daripada hanya dengan memberikan batasan usia nikah.
\end{abstract}

Keywords: Hukum Islam, Pernikahan Dini, Qawaid Fiqhiyah

\section{Pendahuluan}

Sebagai agama mayoritas yang dipeluk penduduk Indonesia, Islam secara otomatis menjadi salah satu sumber nilai di berbagai bidang kehidupan bagi para pemeluknya. Di samping akidah dan akhlak, aspek penting dalam Islam adalah hukum Islam yang masuk ke Indonesia berbarengan dengan masuknya Islam ke Nusantara sejak abad-7 Masehi. Hukum Islam juga menjadi pedoman bagi masyarakat Muslim dalam hal berinteraksi sosial, baik secara individual maupun kelembagaan yang dijalankan oleh para pemimpin pemerintahan dan pemuka agama Islam. Kondisi ini relatif terjaga sejak masa penjajahan hingga masa kemerdekaan.

Pada masa pemerintahan kolonial Belanda, cara pandang masyarakat terhadap hukum Islam di Indonesia memang terjadi perubahan sikap. Pada awalnya, pemerintah kolo- 
nial Belanda menerima seutuhnya hukum Islam sebagai hukum yang berlaku bagi pemeluknya, yang dikenal dengan teori receptie in complexu. Atas usul Snouck Hurgronje, kondisi tersebut berubah, di mana hukum yang diberlakukan adalah hukum adat sedangkan hukum Islam hanya dapat berlaku kalau ia sudah diterima (receptie) dan diadaptasi oleh hukum adat. Teori ini dikenal sebagai theorie receptie. ${ }^{1}$ Meskipun terjadi perubahan sikap tersebut tidak sepenuhnya berdampak dan meniadakan keberadaan hukum Is lam di Nusantara.

Setelah proklamasi kemerdekaan Indonesia tahun 1945, pemimpin dan tokoh politik Islam berusaha meluruskan persepsi tentang pemberlakuan hukum Is lam di Indonesia, baik dengan jalan konstitusional melalui sidang MPR ataupun dengan jalan kekerasan bersenjata seperti dilakukan oleh Kahar Muzakkar, Kartosuwiryo dan Daud Buerueh. Pada perjalanannya, lahir beberapa teori baru yang menolak teori receptie tersebut. Di antaranya teori receptie exit yang dikemukakan oleh Hazairin, teori receptie a contrario oleh Sayuthi Talib, teori eksistensi oleh Ichtianto, dan belakangan teori pembaruan oleh Bustanul Arifin dan rekan-rekannya. $^{2}$ Ada pula teori interdependensi yang dirumuskan oleh A. Qodri Azizi dan teori sinkretisme yang dikemukakan oleh M.B. Hooker. $^{3}$

Terlepas dari itu semua, materi hukum Islam di Indonesia sudah diakui dan dijalankan oleh masyarakat Indonesia. Bahkan ada peradilan agama yang secara khusus memeriksa, mengadili dan memutus perkara-

\footnotetext{
${ }^{1}$ Lihat Andi Tahir Hamid, Beberapa Hal Baru tentang Peradilan Agama dan Bidangnya (Jakarta: Grafika, 2005), h. 3. lihat pula Abdul Halim, Peradilan Agama dalam Politik Hukum di Indonesia (Jakarta: PT Raja Grafindo Persada, 2002), h. 6.

2 Lihat Abdul Manan, Aneka Masalah Hukum Perdata Islam di Indonesia (Jakarta: Kencana, 2006), h. xii.

3 Semua teori di atas mencoba untuk melihat dan menempatkan posisi hukum Islam di Nusantara dengan mempertimbangkan berbagai aspek. Lihat Imam Syaukani, Rekonstruksi Epistemologis Hukum Islam Indonesia (Jakarta: Raja Grafindo Persada, 2006) , h. 88-89.
}

perkara yang muncul di dalam masyarakat muslim, khususnya dalam masalah pernikahan. Namun, karena peraturan-peraturan baku mengenai pernikahan itu sendiri belum ada, pada masa prakemerdekaan, perkara-perkara yang berkaitan dengan pernikahan diserahkan sepenuhnya kepada penghulu dan qadhi untuk memutusnya.

Berkaitan dengan materi hukum Islam tersebut, pada masa kemerdekaan Menteri Agama RI melalui Biro Peradilan Agama mengeluarkan Surat Edaran Nomor B/I/735 pada tanggal 18 Februari 1958 yang ditujukan kepada Pengadilan Agama agar para hakim dalam memeriksa, mengadili, dan memutus perkara supaya berpedoman kepada 13 kitab, yaitu: Al-Bajuri, Fath al-Mu'in, Syarqawi 'ala al-Tahrir, Qalyubi/Muhalla, Fath al-Wahhab, Tuhfah, Targhib al-Musytaq, Qawanin al-Syari'ah Sayyid Dakhlan dan Utsman ibn Yahya, Syamsuri lil Faraidh, Bughyat al-Musytarsyidin, al-Fiqh 'ala Madzahib al- 'Arba'ah dan Mughni al-Muhtaj. ${ }^{4}$

Banyaknya kitab rujukan bagi para hakim dalam memeriksa, mengadili, dan memutus perkara di lingkungan Pengadilan Agama cukup menyulitkan para hakim karena ketentuan yang terdapat dalam kitab-kitab tersebut berbeda satu sama lain. ${ }^{5}$ Di samping itu kitab-kitab di atas lebih mengutamakan madzhab Syafi'i yang ditulis berdasarkan situasi di dunia Arab dan tidak semua umat Islam di Indonesia berpedoman kepadanya sehingga diperlukan formulasi hukum Islam khas Indonesia sebagaimana dikemukakan oleh M. Hasbi Ash-Shidd ieqy. ${ }^{6}$

Langkah awal dari usaha ini adalah pembaharuan UU Nomor 22 tahun 1946 tentang NTR yang diberlakukan pada 22 November 1946, disusul dengan lahirnya Un-

${ }^{4}$ Ibid., h. xiii.

${ }^{5}$ Hal ini merupakan karakteristik dari fiqh sendiri sebagai ilmu yang bersifat dzanni di mana para fuqaha menggali hukum-hukum dari nash-nash alQur'an dan al-Hadist dengan menggunakan ijtihad mereka sendiri yang tentunya berbeda satu sama lain. Lihat Wahbah al-Zuhaili, Ushul al-Fiqh al-Islami (Damaskus: Dar al-Fikr, 1996), h. 18-23.

${ }^{6}$ Lihat Muhammad Hasbi Ash-Shiddieqy, Syari'at Islam Menjawab Tantangan Zaman (Jakarta: Bulan Bintang, 1966), h. 41-42. 
dang-Undang Nomor 1 tahun 1974 tentang Perkawinan, dan PP Nomor 9 tahun 1975 tentang Pelaksanaan Undang-Undang Perkawinan. Selanjutnya lahir pula Kompilasi Hukum Islam yang diberlakukan dengan Instruksi Presiden Nomor 1991.

Kompilasi Hukum Islam dapat dikatakan sebagai ijma para ulama Indonesia yang dirintis sejak kemerdekaan Indonesia. Dalam lokakarya yang diadakan di Jakarta pada 2-5 Februari 1988, para ulama Indonesia yang hadir menerima tiga rancangan buku Kompilasi Hukum Islam, yaitu buku I tentang hukum perkawinan, buku II tentang kewarisan, dan buku III tentang hukum perwakafan. Kompilasi Hukum Islam ini diharapkan dapat digunakan oleh instansi pemerintah dan masyarakat dalam menyelesaikan masalah-masalah hukum Islam yang dihadapi. ${ }^{7}$ Semua usaha ini ditujukan untuk lebih merangkum nilai-nilai hukum Islam secara sistematis sehingga tercipta kepastiaan hukum dalam perund ang-undangan dengan berdasarkan kepada Maqashid al-Syari 'ah.

Namun, secara operasional, keberadaan Undang-Undang Nomor 1 tahun 19974 dan Kompilasi Hukum Is lam sebagai bukti eksistensi hukum Islam di Indonesia tidak diakui oleh beberapa pihak, baik yang berpikiran liberal ataupun konservatif. Mereka beralasan bahwa apa yang termuat dalam KHI tidak mencerminkan hukum Islam itu sendiri. Kaum konservatif tradisionalis sering menggugat ketatnya persyaratan poligami, sementara kaum liberal menggugat aturan yang melarang pernikahan beda agama. Hal ini dapat dilihat dalam Counter Legal Draf Kompilasi Hukum Islam yang dimotori oleh Siti Musdah yang isinya banyak menggugat masalah perwalian bagi anak perempuan, waris, poligami dan perkawinan beda agama yang ada dalam Kompilasi Hukum Islam.

Kond isi ini mengesankan bahwa eksistensi Kompilasi Hukum Islam tidak memiliki dasar hukum Islam dalam masyarakat.

7 Pada dasarnya apa yang termuat dalam KHI yang berhubungan dengan perkawinan semuanya telah dimuat dalam UU No. I Tahun 1974 jo. PP No. 9 1975. Mengenai KHI, lihat Abdul Mannan, Aneka Masalah Hukum, h. 26.
Masyarakat muslim terkadang lebih berpedoman kepada kitab-kitab fiqh daripada kepada materi Hukum Islam yang sudah dimasukkan ke dalam sistem Undang-Undang di Indonesia. Hal ini tentu menggambarkan adanya ambiguitas antara hukum Islam (fiqh) dan KHI, sehingga disana terjadi dualisme hukum yang justru akan membingungkan masyarakat itu sendiri.

Kasus yang akhir-akhir ini mencuat dan menjadi cermin dualisme hukum Islam di Indonesia adalah pernikahan Syekh Puji dengan Lutfiana Ulfa yang tengah menjadi sorotan luas masyarakat di Indonesia dan disajikan secara luas oleh media cetak dan elektronik. Kasus ini menarik karena kesenjangan usia antara keduanya sangat jauh; Syekh Puji berusia 43 tahun sementara Ulfa berusia 12 tahun. Usia Ulfa tidak memenuhi syarat usia minimum pernikahan yaitu 19 tahun untuk calon suami dan 16 tahun untuk calon isteri. ${ }^{8}$ Meskipun pernikahannya dengan Ulfa memunculkan kontroversi di tengah masyarakat luas, khususnya Komnas Anak, karena melanggar Undang-undang Perkawinan No. I tahun 1974 tentang batas minimum usia menikah, Syekh Puji tetap berkeyakinan bahwa pernikahannya adalah sah karena sudah sesuai dengan syari'at. Keyakinan tersebut dikuatkan dengan kerelaan Ulfa dan keinginannya untuk tetap hidup bersama Syekh Puji sebagai isteri.

Kasus pernikahan dini ini penulis angkat sebagai salah satu contoh fenomena problematika dualisme hukum Islam dalam masyarakat muslim. Penulis akan menganalisis kasus tersebut dari perspektif Qawaid Fiqhiyah dan Siyasah Syar'iyah.

${ }^{8}$ Ketentuan ini dapat dilihat dalam Kompilasi Hukum Islam pasal 15 yang berbunyi: (1) Untuk kemaslahatan keluarga dan rumah tangga, perkawinan hanya boleh dilakukan calon mempelai yang telah mencapai umur yang ditetapkan dalam pasal 7 Undang-undang No. 1 tahun 1974 yakni calon suami sekurang-kurangnya berumur 19 tahun dan calon isteri sekurang-kurangnya berumur 16 tahun. 


\section{Pro-Kontra Pernikahan Dini dalam Pers- pektif Fiqh Klasik}

Pernikahan dini dalam kitab fiqh klasik biasa disebut dengan nikah al-shaghir/alshaghirah, yaitu pernikahan yang dilakukan oleh seseorang laki-laki atau perempuan yang belum baligh. Dalam perspektif fiqh, usia baligh seseorang dicirikan dengan ihtilam (mimpi basah) bagi seorang laki-laki dan keluarnya darah haid bagi seorang perempuan. Dari sisi usia, menurut Abu Hanifah bagi laki-laki adalah 18 tahun dan perempuan 17 tahun. Sementara menurut Syafi'i usia baligh adalah 15 tahun baik bagi laki-laki ataupun perempuan. ${ }^{9}$

Hukum pernikahan dini menurut mayoritas ulama adalah sah apabila telah memenuhi syarat dan rukun pernikahan yang telah ditentukan yaitu shighat (ijab-qabul), calon mempelai (suami-isteri), wali bagi perempuan dan dua saksi. ${ }^{10}$ Namun ada juga ulama yang tidak membolehkan pernikahan dini dengan beberapa argumentasi dan dalil.

Ulama yang mensahkan pernikahan dini mengemukakan dalil dan argumentasi sebagai berikut:

1. QS. 65:4

"Bagi mereka yang telah putus haidnya (monopause) masa tunggunya adalah 3 bulan. Demikian juga bagi mereka yang belum haid"

Dalam ayat ini disebutkan bahwa iddah (masa tunggu) bagi wanita yang belum haid dan wanita yang sudah monopause adalah 3 bulan. Adanya iddah bagi wanita yang belum haid menunjukkan kebolehan menikahinya karena iddah tidak mungkin terjadi tanpa didahului pernikahan dan perceraian.

2. QS. 24: 32

"Dan nikahkanlah wanita-wanita yang belum bersuami di antara kalian"

9 Lihat Sulaiman al-Bujairimi, Bujairimi 'ala al-Khatib, juz IV (Beirut: Dar al-Fikr, 2007), h. 71

10 Lihat Muhammad Nawawi ibn 'Umar alJawi, Tausyikh 'ala Ibn Qasim Qut al-Habib al-Gharib (Beirut: Dar al-Fikr, 1996), h. 198. Ketentuan ini juga menjadi rukun pernikahan di dalam Ko mpilasi Hukum Is lam pasal 14.
Perintah dalam ayat ini menggunakan kata الأيامي (wanita-wanita) dalam ayat ini bermakna 'am (umum) yang mencakup semua perempuan baik yang sudah baligh ataupun belum. Mengenai lafadz 'am para ulama usul sepakat bahwa semua kata yang bersifat umum dapat mencakup semua makna yang tercakup di dalamnya apabila tidak ada dalil yang mentakhsisnya. ${ }^{11}$

3. Pernikahan Nabi dengan Siti 'Aisyah sebagaimana tertulis dalam beberapa hadis.

'Nabi menikahiku ketika aku berusia 6 tahun dan hidup bersama denganku ketika aku berusia 9 tahun". ${ }^{12}$

4. Riwayat dan atsar dari para sahabat yang menikahkan kerabat mereka yang masih kecil. Seperti Ali ibn Abi Thalib yang mengakadkan pernikahan Ummi Kultsum dengan 'Urwah ibn Zubair, dan 'Abdullah ibn al-Hasan ibn 'Ali dengan wanita yang masih kecil. Sahabat-sahabat lain seperti Ibn alMusayyab dan 'Abdullah ibn Mas'ud juga membolehkan pernikahan di bawah umur. ${ }^{13}$

5. Sahnya pernikahan dini juga didasarkan kepada kemaslahatan yang terkandung dalam menikahkan anak kecil, seperti telah ditemukannya calon yang ideal ( $k u f u)$ bagi si wanita. $^{14}$

${ }^{11}$ Mengenai lafadz 'am para ulama ushul sepakat bahwa semua lafadz yang bersifat umum (' $a m$ ) dapat mencakup semua makna yang tercakup di dalamnya apabila tidak ada dalil yang mentakhsisnya. Lebih lanjut lihat 'Abdul Wahhab Khallaf, Ushul alFiqh (Kuwait: Dar al-'Ilm, 1978), h. 183.

12 Hadis ini telah disepakati keshahihannya oleh al-Bu khari, Muslim dan Ahmad ibn Hanbal. Lihat Muhammad ibn 'Ali al-Syaukani, Nayl al-Authar jilid III (Beirut: Dar al-Fikr, 2000), h. 232. Meskipun ada kemungkinan hadist ini terjadi ketika belum ada perintah untuk meminta ijin kepada seorang perawan ketika akan dinikahkan sebagaimana pendapat Ibn Hajar al-Asqalani, menurutnya hal ini sangat mungkin terjadi karena persitiwa in i terjadi di Makkah

13 Lihat Wahbah al-Zuhaili, al-Fiqh al-Islami wa Adillatuh, juz IX, (Damaskus: Dar al-Fikr alMu'ashir, 2006), h. 6683.

14 Ibid 
6. Sahnya pernikahan ini juga didasarkan pada prinsip bahwa baligh bukanlah merupakan syarat sahnya per- nikahan. ${ }^{15}$

Sedangkan Ulama yang tidak membolehkan pernikahan seseorang yang belum baligh seperti Ibn Syubrumah, Abu Bakr al'Asham dan Utsman al-Batti berpedoman kepada dalil berikut:

\section{QS. 4:6}

"Dan ujilah anak yatim itu sampai mereka cukup umur untuk menikah. Kemudian jika menurut pendapatmu mereka telah cerdas (pandai memelihara harta), maka serahkanlah kepada mereka harta-harta mereka."

Meskipun secara eksplisit tidak menerangkan tentang kondisi baligh sebagai salah syarat pernikahan, ayat ini mengandung makna bahwa kelayakan seseorang untuk menikah dibatasi oleh usia baligh dan rusyd (kepandaian) seseorang dalam mengurus harta. ${ }^{16}$ Menurut Ibn Hazm jika anak-anak yang masih kecil dibolehkan menikah maka esensi ayat ini akan terabaikan. ${ }^{17}$

2. Orang yang belum baligh dipandang belum mengerti esensi dan tujuan menikah sehingga pernikahan dini justru akan menyebabkan madarat mengingat begitu beratnya beban tanggung jawab di dalam kehidupan pernikahan.

\section{Syarat Pernikahan Dini dalam Pe rspektif Kitab-kitab Fiqh}

Meskipun mayoritas ulama membolehkan pernikahan dini, namun tidak berarti bahwa pernikahan ini dapat dilaksanakan tanpa syarat. Ada beberapa syarat yang harus dipenuhi:

1. Menurut Ulama Malikiyah, Syafi'iyah dan Hanabilah, pihak yang berhak me-

${ }^{15}$ Lihat Sayyid Sabiq, Fiqh Sunnah, juz II (Beirut: Dar al-Fikr, 1983), h. 115.

16 Lihat Ahmad Musthafa al-Maraghi, Tafsir al-Maraghi, juz II (Beirut: Dar al-Fikr, 2001), h. 108.

${ }^{17}$ Lihat Wahbah, al-Fiqh, h. 6682. langsungkan pernikahan tersebut hanyalah ayah, kakek dan hakim. ${ }^{18}$

2. Ulama Syafi'iyah menetapkan enam syarat yang harus dipenuhi dalam pernikahan dini, yaitu:

a) Antara ayah dan anak tidak terjadi permusuhan.

b) Ayah anak tersebut harus meminta mahar mitsl (maskawin yang sesuai kebiasaan setempat) kepada calon suaminya.

c) Maskawin tersebut berupa mata uang yang berlaku di daerahnya.

d) Calon suami dari anak tersebut bukan orang yang kesulitan dalam memberikan maskawin.

e) Ayah anak tersebut tidak menikahkan dengan orang yang akan memberatkannya, seperti orang buta atau orang yang sangat tua.

f) Anak perempuan tersebut belum mempunyai kewajiban haji, karena adakalanya seorang suami mencegah isterinya haji dengan alasan haji bisa ditunda padahal anak tersebut ingin segera melaksanakannya. ${ }^{19}$

\section{Usia Pernikahan dalam Kompilasi Hukum Islam}

Undang-undang Nomor 1 tahun 1974 dan Kompilasi Hukum Islam memuat asas penting yang harus dipenuhi dalam pernikahan, diantaranya adalah asas kematangan

18 Sebagai wali, ayah juga harus memenuhi syarat sebagai berikut: Islam, berakal, dan adil. Keadilan yang dimaksud di sini adalah kemampuan untuk mencegah diri dari melakukan dosa dan sesuatu yang hina walaupun secara hukum dibolehkan. Lebih lanjut, lihat Muhammad al-Syarbini al-Khatib, alIqna' (Beirut: Dar al-Fikr, 2005), h. 409. Di samping syarat-syarat tersebut ada syarat yang harus dipenuhi seorang ayah yang memaksa anaknya menikah yaitu: si gadis belum pernah bersetubuh sebelumnya, ia dinikahkan dengan laki-laki yang setara dengan mahar mitsil (mas kawin yang lazim). Lihat Muhammad Qasim al-Ghazi, Fath al-Qarib (Surabaya: al-Huda, tt), h. 91. Imam al-Nawawi menambah syarat yang lain yaitu tidak adanya permusuhan antara si ayah dan anak perempuannya. Lihat Abu Zakariya al-Nawawi, Raudhah al-Thalibin, juz VI (Beirut: Dar al-Fikr, 2005), h. 48.

${ }^{19}$ Lihat Wahbah, al-Fiqh, h. 6686. 
atau kedewasaan calon mempelai. Asas ini juga diterapkan oleh sekitar 17 (tujuh belas) negara muslim, dengan batas minimal usia pernikahan yang berbeda-beda. ${ }^{20}$

Ketentuan usia calon mempelai diatur di dalam Kompilasi Hukum Islam pasal 15 yang berbunyi:

(1) Untuk kemaslahatan keluarga dan rumah tangga, perkawinan hanya boleh dilakukan calon mempelai yang telah mencapai umur yang ditetapkan dalam pasal 7 Undang-Undang No. 1 tahun 1974 yakni calon suami sekurangkurangnya berumur 19 tahun dan calon isteri sekurang-kurangnya berumur 16 tahun.

(2) Bagi calon mempelai yang belum mencapai umur 21 tahun harus mendapati izin yang diatur dalam pasal 6 ayat (2), (3), (4) dan (5) UU No. 1 Tahun 1974.

Kompilasi Hukum Islam dalam hal ini memang tidak memberikan aturan yang berbeda dari UU No. 1 Tahun 1974, akan tetapi ia menjelaskan pertimbangan hukum yang digunakan di dalam menetapkan peraturan ini, yaitu sebagai upaya kemaslahatan yang tidak diterangkan di dalam Pasal 7 UU No. 1 tahuin 1974.

Akan tetapi kalau kita cermati, UndangUndang No. 1 tahun 1974 dan Kompilasi Hukum Islam pada dasarnya tidak menutup peluang pihak yang ingin menikah atau menikahkan anaknya pada usia di bawah batas usia minimum bolehnya pernikahan. Proses dan prosedur untuk itu sudah diterangkan di dalam pasal 7 ayat (1) dan (2) UU No. 1 tahun 1974 yaitu:

(1) Perkawinan hanya diizinkan jika pihak pria sudah mencapai umur 19 tahun (sembilan belas) tahun dan pihak wanita sudah mencapai umur 16 (enam belas) tahun.

(2) Dalam hal penyimpangan terhadap ayat (1) pasal ini dapat meminta dispensasi kepada Pengadilan atau

${ }^{20}$ Lebih lanjut lihat A min Suma, Hukum Keluarga Islam di Dunia Islam (Jakarta: PT. Raja Grafindo Persada, 2004), h. 183.
Pejabat lain, yang ditunjuk oleh kedua orang tua pihak pria maupun wanita.

Semua ketentuan sebagaimana diterangkan dalam UU. No 1 tahun 1974 berlaku sepanjang hukum masing-masing agama dan kepercayaan dari yang bersangkutan tidak menentukan lain, sebagaimana disebutkan dalam pasal 6 (6).

Dalam kasus ini, sebenarnya Syekh Puji masih memiliki peluang hukum untuk mengajukan dispensasi ke Pengadilan Agama. Namun dispensasi tersebut ditolak Pengadilan Agama karena pernikahan tersebut sudah terjadi, dan Syekh Puji seharusnya mengikuti prosedur lain berupa pengajuan permohonan izin untuk beristri lebih dari seorang, namun prosedur alternatif ini juga tidak ditempuh.

Terlepas dari niat baik Syekh Puji untuk mendidik Ulfa dalam pernikahan, banyak pasal dan ketentuan hukum yang tidak dipenuhi oleh Syekh Puji dalam menaati hukum perkawinan di Indonesia.

\section{Pernikahan Syekh Puji dalam Perspektif Qawaid Fiqhiyah}

Dilihat dari perspektif fiqh, pernikahan Syekh Puji dengan Ulfa adalah sah karena mayoritas ulama membolehkannya dan Ulfa sendiri sudah tidak dapat dikatakan shaghirah (anak-anak) lagi karena ia sudah baligh dan bisa menyatakan pendapatnya sendiri. Akan tetapi jika dilihat dari perspektif Kompilasi Hukum Islam dan Undang-Undang yang berlaku di Indonesia pernikahan tersebut tidak sah dan tidak memiliki kekuatan hukum.

Pertentangan dan dualisme hukum ini apabila didekati dari sudut Qawaid Fiqhiyah dan Siyayah Syar'iyah sebenarnya dapat diminimalisir melalui beberapa aspek:

1. Merupakan kewajiban bagi pemerintah untuk menjaga kemaslahatan rakyatnya sehingga semua kebijakannya harus didasarkan pada kemaslahatan. ${ }^{21}$

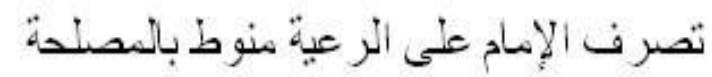

2. Perbedaan aturan di dalam kitab fiqh yang berkaitan dengan ketentuan publik ti-

21 lihat Taqi al-Din Ibn Tay miyah, al-Siyasat al-Syar 'iyyat fi Ishlah al-Ra i wa al-Ra iyyah (Beirut: Dar al-Fikr al-Haditsah, tt), h. 173. 
daklah serta merta dapat menjadi pedoman hukum, tapi harus diatur dan ditetapkan serta diakui terlebih dahulu oleh hakim dan dijadikan panutan oleh masyarakat. Hal tersebut perlu dilakukan untuk menjauhkan dualisme hukum yang akan membingungkan masyarakat. Hal ini sesuai dengan kaidah bahwa "keputusan hakim adalah mengikat dan menghilangkan perbedaan pendapat".

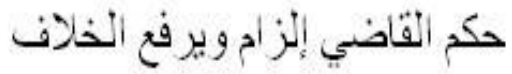

Kemaslahatan sebagai landasan hukum dalam pembatasan usia pernikahan sangatlah relevan apabila dilihat dari perspektif psikologis dan sosial. Pada umumnya wanita yang berusia di bawah 16 tahun secara psikologis belumlah cukup rusyd (cakap) dan siap untuk menanggung beban pernikahan yang sangat berat. $^{22}$ Sedangkan kondisi Ulfa yang memang sudah terlihat cerdas tidaklah dapat dijadikan dasar umum untuk melihat wanita yang lain. Hal ini sesuai dengan kaidah bahwa, "patokan umum didasarkan pada sesuatu yang sering terjadi, bukan pada sesuatu yang jarang terjadi", 23

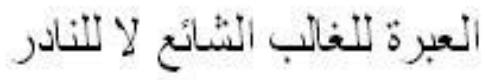

3. Niat Syekh Puji untuk menyediakan pendidikan dan jaminan hid up kepada Ulfa di dalam pernikahan bisa jadi justru mengandung kemadaratan mengingat belum matangnya kond isi psikologis dan alat reproduksinya dalam menjalani pernikahan. Jika kemaslahatan dan kemadaratan bertemu, maka menurut qaidah fiqhiyah, "pencegahan kemadaratan harus didahulukan dari pada perolehan kemaslahatannya",24

$$
\text { در + أنفاسد أُولى من جلب أمصاح }
$$

Diperlukan elaborasi mendalam, baik qowaid fiqhiyah maupun siyasah syar'iyah. Bagaimana hubungan antar keduanya, dalam kasus nikah dini.

22 Di dalam Q.S. al-Nisa: 21, nikah disebut sebagai perjanjian yang kokoh.

${ }^{23}$ Lihat Ahmad ibn Syaikh Muhammad al-Zarqa, Syarh al-Qawa id al-Fiqhiyyah, (Damaskus: Dar al-Qalam, 1989), h. 235.

24 Ibid., 205

\section{Fiqh vis-a-vis Kompilasi Hukum Islam dalam Perspektif Penerapan Hukum Hu- kum Islam di Indonesia}

Fiqh sebagai ilmu yang sudah sangat melekat di kalangan umat Islam dan diajarkan secara luas tentu memiliki nilai historis sendiri bagi umat Islam. Ketentuan-ketentuan pernikahan yang sudah baku di dalam kitabkitab fiqh klasik seringkali menyulitkan posisi Kompilasi Hukum Islam yang baru ditetapkan pada tanggal 22 Juli 1991 lewat Instruksi Presiden No. 154. Kesulitan itu tampak nyata ketika terjadi perbedaan aturan antara keduanya, misalnya mengenai batas minimum usia pernikahan. Masyarakat seringkali memandang aturan pernikahan dalam kitab-kitab fiqh sebagai hukum pernikahan yang baku, sehingga materi hukum Islam yang termuat dalam KHI sulit diaplikasikan di dalam masayarakat. Sebenarnya, jika pasal-pasal di dalam KHI dipelajari dengan seksama, tampak bahwa materi isinya selain mengandung nilai-nilai hukum yang sudah diadaptasi ke dalam dan menjadi kesadaran hukum masyarakat muslim, juga mengandung hal-hal baru yang bercorak khas Indonesia. $^{25}$

KHI seharusnya dapat dimaknai sebagai ijtihad jama'i dawli (ijtihad kolektif bangsa) dimana sekelompok ulama Indonesia dari berbagai disiplin ilmu dan keahlian berkumpul untuk menetapkan suatu hukum yang berlaku di Indonesia dan tentu saja telah mengalami pergeseran dari garis-garis besar Syari'ah Islam. ${ }^{26}$

Dengan demikian KHI seharusnya tidak dipertentangkan dengan kitab-kitab fiqh. Pertentangan antara KHI dengan kitab-kitab fiqh selain tidak berdasar juga berdampak negatif terhadap kepastian hukum di Indo-nesia yang sangat plural ini. Sekiranya perlu ada perubahan dalam materi KHI karena ketidaksesuaiannya dengan kondisi nyata masyarakat

25 Lihat Mohammad Daud Ali, Hukum Islam Pengantar Ilmu Hukum dan Tata Hukum Islam Indonesia (Jakarta: Raja Grafindo Persada, 2006), h. 336.

26 Mengenai pengertian istilah ijtihad jama $i$ lihat A. Qodri Azizy, Reformasi Bermazhab Sebuah Ikhtiar menuju Ijtihad Saintifik-Modern (Jakarta: Teraju, 2003), h. 85. 
Indonesia, maka hal itu tentunya juga harus dibahas melalui prosedur perubahan materi hukum sebagaimana mestinya.

Dalam kasus pernikahan di bawah umur, jika kita cermati sebenarnya KHI tidak menutup kemungkinan menegasikan pernikahan di bawah umur mengingat adanya kondisi khusus dalam masyarakat. Kondisi tertentu bisa jadi menuntut seseorang untuk menikah dini sesuai kebutuhannya. Akan tetapi kebutuhan tersebut harus terlebih dahulu diuji objektifitas hukumnya di depan majlis hakim sehingga pernikahan tersebut tidak semata-mata berdasarkan kebutuhan subjektif dengan mengorbankan serta merugikan pihak -pihak lain.

Problematika dualisme yang dipicu oleh sikap masyarakat yang belum memandang KHI sebagai bentuk wajah fiqh Indonesia dan hukum yang berlaku di Indonesia, sebenarnya juga dilatarbelakangi oleh beberapa hal, di antaranya:

1. Kurangnya sosialisasi materi hukum yang ada di dalam Kompilasi Hukum Islam dan Undang-Undang Nomor 1 tahun 1974 sehingga masyarakat tidak mengetahui prosedur dan hukum pernikahan di Indonesia.

2. Kurang terlibatnya tokoh-tokoh agama Islam dalam pembahasan materi UndangUndang pernikahan dan Kompilasi Hukum Islam.

3. Banyaknya oknum peradilan yang terbukti melakukan pelanggaran-pelanggaran sehingga berimbas pula kepada ketidak-per-

\section{DAFTAR PUSTAKA}

Ali, Mohammad Daud. 2006. Hukum Islam Pengantar Ilmu Hukum dan Tata Hukum Islam Indonesia. Jakarta: RajaGrafindo Persada.

Ash-Shiddieqy, Muhammad Hasbi. 1966. Syari'at Islam Menjawab Tantangan Zaman. Jakarta: Bulan Bintang.

Azizy, A. Qodri. 2003. Reformasi Bermazhab

Sebuah Ikhtiar menuju Ijtihad Saintifik-

Modern. Jakarta: Teraju. cayaan masyarakat umum terhadap materi undang-undang di dalamnya.

4. Tidak dimasukkannya Kompilasi Hukum Islam dalam materi pengajaran di pesantren-pesantren dan lembaga pendidikan Islam lainnya sehingga mereka lebih mengenal hukum pernikahan di dalam kitab-kitab fiqh daripada hukum pernikahan di dalam Kompilasi Hukum Islam.

5. Kurang tegasnya sanksi bagi mereka yang melanggar ketentuan tentang pernikahan.

\section{Kesimpulan}

Dari pemaparan di atas dapat disimpulkan bahwa persoalan pernikahan dini dalam perspektif fiqh dan KHI sebenarnya harus bermuara pada kemaslahatan bagi semua pihak. Apabila perkawinan dini dikhawatirkan akan menimbulkan kemadara-tan dan keburukan terhadap salah satu pihak, maka pemerintah sebagai pihak yang bertanggung jawab terhadap kesejahteraan dan kemaslahatan masyarakat luas mempunyai hak dan kewajiban untuk mengatur dan menetapkan aturan hukum dalam urusan pernikahan tersebut.

KHI harus dimaknai sebagai hasil ijtihad jama'i dawli yang mempunyai kekuatan hukum untuk menyelesaikan berbagai problem sosial kemasyarakatan di Indonesia, tanpa harus mempertentangkannya dengan ketentuan-ketentuan hukum yang ada dalam kitab fiqh yang sangat bervariasi.

Bujairimi, Sulaiman. 2007. Bujairimi 'ala alKhatib (jilid IV). Beirut: Dar al-Fikr.

Ghazi, Muhammad Qasim. tt. Fath al-Qarib. Surabaya: al-Huda.

Hamid, Andi Tahir. 2005. Hal Baru tentang Peradilan Agama dan Bidangnya. Jakarta: Grafika.

Halim, Abdul. 2002. Peradilan Agama dalam Politik Hukum di Indonesia. Jakarta: PT RajaGrafindo Persada. 
Ibn 'Umar al-Jawi, Muhammad al-Nawawy. 1996. Tawsyikh 'ala Ibn Qasim Qut alHabib al-Gharib. Beirut: Dar al-Fikr.

Khallaf, Abd al-Wahhab. 1978. Ushul alFiqh. Kuwait: Dar al-'Ilm.

Khathib, Muhammad al-Syarbini. 2005. alIqna'. Beirut: Dar al-Fikr.

Manan, Abdul. 2006. Aneka Masalah Hukum Perdata Islam di Indonesia. Jakarta: Kencana

Maraghi, Ahmad Musthafa. 2001. Tafsir alMaraghi (jilid II). Beirut: Dar al-Fikr.

Nawawy, Abu Zakariya al-Nawawi. 2005. Raudlah al-Thalibin (jilid VI). Beirut: Dar al-Fikr.

Sabiq, Sayyid. 1983. Fiqh al-Sunnah (jilid II). Beirut: Dar al-Fikr.
Suma, Amin. 2004. Hukum Keluarga Islam di Dunia Islam. Jakarta: PT. RajaGrafindo Persada.

Syaukani, Imam. 2006. Rekonstruksi Epistemologi Hukum Islam Indonesia. Jakarta: RajaGrafindo Persada.

Syaukani, Muhammad Ibn 'Ali. 2000. Nail al-Authar (jilid III). Beirut: Dar al-Fikr.

Taimiyah, Taqi al-Din Ibn. tt. Al-Siyasah alSyar'iyyah fi Ishlah al-Ra'i wa alRa 'iyyah. Beirut: Dar al-Fikr al-Haditsah.

Zarqa, Ahmad ibn Syaikh Muhammad. 1989. Syarh al-Qawa id al-Fiqhiyyah. Damaskus: Dar al-Qalam.

Zuhaili, Wahbah. 1996. Ushul al-Fiqh alIslami (jilid I). Damaskus: Dar al-Fikr 2006. Al-Fiqh aI-Islami wa Adillatuh. Damaskus: Dar al-Fikr al-Mu'ashir. 
Problematika Implementasi Hukum Islam Terhadap Perkawinan Di Bawah Umur Di Indonesia 